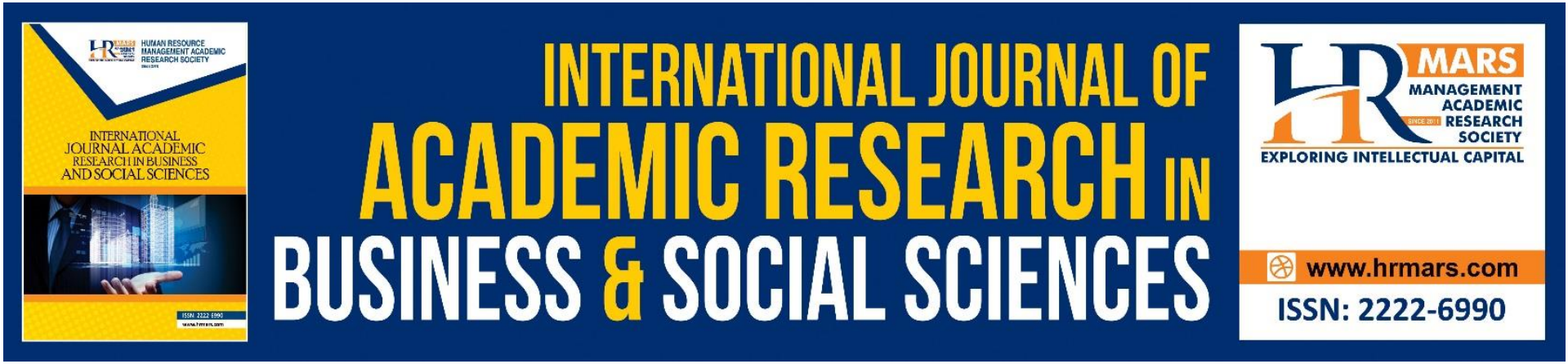

\title{
The Consumption of Popular Culture Products among Japanese Language Learners at Universiti Teknologi Mara
}

Normah Ahmad, Roslina Mamat

To Link this Article: http://dx.doi.org/10.6007/IJARBSS/v12-i1/12183

DOI:10.6007/IJARBSS/v12-i1/12183

Received: 09 November 2021, Revised: 10 December 2021, Accepted: 27 December 2021

Published Online: 17 January 2022

In-Text Citation: (Ahmad \& Mamat, 2022)

To Cite this Article: Ahmad, N., \& Mamat, R. (2022). The Consumption of Popular Culture Products among Japanese Language Learners at Universiti Teknologi Mara. International Journal of Academic Research in Business and Social Sciences, 12(1), 1598-1607.

Copyright: @ 2022 The Author(s)

Published by Human Resource Management Academic Research Society (www.hrmars.com)

This article is published under the Creative Commons Attribution (CC BY 4.0) license. Anyone may reproduce, distribute, translate and create derivative works of this article (for both commercial and non0-commercial purposes), subject to full attribution to the original publication and authors. The full terms of this license may be seen at: http://creativecommons.org/licences/by/4.0/legalcode

Vol. 12, No. 1, 2022, Pg. $1598-1607$

Full Terms \& Conditions of access and use can be found at http://hrmars.com/index.php/pages/detail/publication-ethics 


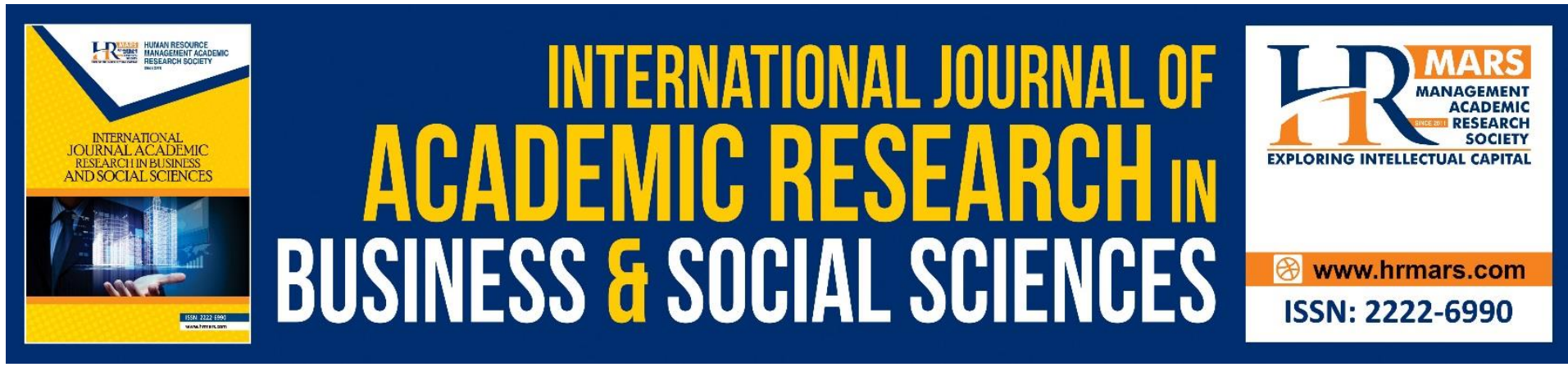

\title{
The Consumption of Popular Culture Products among Japanese Language Learners at Universiti Teknologi Mara
}

\author{
Normah Ahmad ${ }^{1}$, Roslina Mamat ${ }^{2}$ \\ ${ }^{1}$ Academy of Language Studies Universiti Teknologi MARA Shah Alam, ${ }^{2}$ Faculty of Modern \\ Languages and Communication, University Putra Malaysia \\ Email: normah698@uitm.edu.my¹, linamm@upm.edu.my²
}

\begin{abstract}
Today, Japanese popular culture stands as one of the leading and most prominent popular cultures around the world. Many researchers from the West studied Japanese popular culture and its relation to various aspects, namely teaching and learning Japanese, tourism, product selling, and also cultural exchange between Japan and the rest of the world. The current study aims to investigate the consumption of Japanese popular culture products among the Japanese language learners at Universiti Teknologi MARA (UiTM). The result from the study indicates that the consumption of Japanese popular culture products is high among Japanese as a Foreign Language (JFL) learners, and this could be implied that they are very interested in anime, manga, song, and seiyu (voice actor), and these are used as a tool to improve their proficiency in the Japanese language.
\end{abstract}

Keywords: Popular Culture, Manga, Anime, Japanese Language Learners

\section{Introduction}

Foreign language learning is becoming more popular in Malaysian universities. For a long time, most colleges, particularly public universities, have offered foreign language courses. This demonstrates that the importance of learning foreign languages has been recognised by individuals in the academic field. In fact, learning a global or foreign language has been listed as one of the crucial components in spearheading Malaysia's aim of being a fully developed nation in the Malaysian Education Blueprint 2015-2025 (Higher Education).

In Malaysia, Japanese is taught as one of the foreign languages in public universities and government secondary schools. In most Malaysian colleges, Japanese is consistently recognised as one of the top four most popular languages. In some universities, the Japanese language is in the top position along with Mandarin and Arabic. It is difficult to identify which is the most popular language based on the number of students alone. This is because both Korean and Japanese are foreign languages in Malaysia, compared to Chinese and Arabic, which are also foreign languages, but with many more speakers. Meanwhile, Mandarin is the native language of the Chinese, and Arabic is the second language of some Malays.

Universiti Teknologi MARA (UiTM) started offering Japanese language courses in the early 1970 s but only made this course an elective compulsory in 1999. Japanese is one of the seven 
languages offered at UiTM, in addition to Arabic, Mandarin, French, German, Korean, and Italy. There are more than 3000 students studying Japanese at UiTM at one time, making it one of the courses that has always been the choice of students. Currently, Japanese has the largest number of students after Arabic and Mandarin. The number of students taking Japanese language courses at UITM is the largest among Japanese language students at other public universities in Malaysia.

\section{Japanese Language Syllabus in UiTM}

In most cases, the university has delegated responsibilities for using a specific textbook, module, or method to the faculty or academy. As a result, textbooks and syllabi differ from one another. Universiti Putra Malaysia (UPM), Universiti Malaysia Terengganu (UMT), for example, use the Minna no Nihongo textbook, whereas UiTM, Universiti Malaysia Sarawak (Unimas), and Universiti Sains Islam Malaysia (USIM) use the Marugoto textbook (Roslina, 2021). Although several universities utilize the same textbook, each university's syllabus and the level of learning differs since it is dependent on the decisions made by each language unit in the Faculty/ Academy.

The Japanese language course taught at UiTM consists of three levels, namely level 1 , level 2, and level 3. The textbook used is Marugoto Katsudo, which is used for 3 semesters. The syllabus used in Marugoto Katsudo covers the Japan Standard syllabus at A2 level. Language Learning is done using Romaji (alphabet), but Katakana and Hiragana are also taught. Marugoto is more focused on intercultural communication, whereas the Minna no Nihongo textbook is more focused on grammar and comprehension.

The advantage of the Marugoto textbook is that it is equipped with online learning exercises and activities, namely Marugoto Plus and e-Minato, which can be used for free. Students only need to register on the e-Minato platform and do various additional exercises. Since the Covid-19 pandemic hit the world, all language classes have switched to online. Marugoto textbooks are very timely and suitable for use in online teaching and learning situations because Marugoto provides a self-paced learning platform that can be done by students anytime and anywhere. This situation is conducive to online teaching and learning.

\section{Japanese Language Society Activities in UiTM}

Japanese language students at UITM have an active Japanese language association known as the Japanese Language Society (JLS). Various students activities are conducted throughout the semester. Before the pandemic began, many activities were done face-to-face. One of the biggest events organized by JLS is the Japan Festival known as JFest. Among the activities carried out are Japanese food stalls, karaoke competitions, cosplay, and various other activities were carried out to introduce Japanese culture to the campus community. As a result of the Covid-19 pandemic, where learning has transferred to online classes, students' association activities have also shifted to the Internet. Free Japanese language sessions are held on a regular basis, and the teaching staff includes both students and lecturers. The biggest event organized by JLS in this pandemic is the "Virtual Ramen Date" which involves the participation of foreign participants such as Japan, Indonesia, and Thailand. The program, among others, gathers ramen fans and gives participants the opportunity to exchange information about ramen. A video-making competition to prepare ramen and also to make a poster about ramen was also carried out. The activities conducted by JLS indirectly cultivate students' interest in Japanese culture including Japanese popular culture. 


\section{Problem Statement}

UiTM students are unique in a way that all students are Bumiputras with a percentage of Malay students exceeding 90 percent. Hence, this paper attempts to find out and examine the use of Japanese popular culture among UiTM students, given that there has been no such study conducted on UiTM students. This study can be utilised as a basis for paving the way for a more in-depth study of the use of Japanese popular culture among Malay and Muslim adolescents.

The objectives of this paper are:

- To investigate the use of Japanese popular culture products among UiTM students.

- To investigate to what extent the students' involvement in Japanese popular culture.

\section{Literature Review}

Many people associate the word "Japanese popular culture" with manga, anime, and J-pop. Scholars, critics, and policymakers worldwide, not just in Japan, have struggled to come up with a common definition of "popular culture." Seaton and Yamamura (2015), highlighted that the use of "pop culture" in cultural diplomacy was the subject of a report commissioned by the Japanese Ministry of Foreign Affairs in 2006. The Ministry defined "pop culture" (poppu karucha) as "culture produced in ordinary people's everyday lives" (ippan shimin ni yoru nichijo no katsudo de seiritsu shite iru bunka), a definition that they admitted allowing forms categorised as "traditional culture" by many, such as ukiyo-e, pottery, and the tea ceremony, to be classified as poppu karucha along with anime and manga.

Manion (2014), investigated anime and learning Japanese culture in several universities in the United States. She looked at the role of anime in stimulating interests in Japan, and the ways in which interests in anime and Japanese popular culture are closely related to an interest in Japan. She also put anime fandom on a scale of the people's involvement. At one end of the scale, there are newcomers and people who like anime but don't become deeply involved with the fan community, and at the other end, there is the otaku, who are deeply involved with anime and Japanese popular culture. People who are at the otaku end of the scale have greater contact with and knowledge of Japan, and their activities encourage less involved fans to become more interested, thus enhancing their own knowledge of Japan.

In Malaysia, studies on the use of Japanese popular culture are still scarce. However, there are a few studies that have been conducted recently by local researchers. Roslina Mamat is one of the active researchers who has investigated in recent years. Roslina et al (2019) have made a comparative study of the history of the development of manga and animation between Malaysia and Japan. Their study shows that manga had existed in Japan for a long time before the Meiji era. At the same time, comics in Malaysia began in the early 1950s. Animation in Japan started in the 1950s, while in Malaysia, animation started in the 1970s.

In 2021, Roslina collaborated with Universiti Putra Malaysia, Universiti Malaya, Universiti Kebangsaan Malaysia, Universiti Malaysia Sarawak, and Universiti Malaysia Terengganu on a study on Japanese popular culture in Japanese language acquisition. Roslina et al. investigated manga and anime as a learning medium among Japanese language students in Malaysia Public Universities, namely a collaboration between the Universiti Putra Malaysia and the University of Malaya, in 2018. Despite the fact that these two studies are nearly 
comparable, Roslina's (2021) study revealed that students prefer to use the latest Japanese popular culture, notably VTuber, in addition to manga and anime.

Notably, Chan and Wong (2017) specifically investigated the use of anime in Japanese language education. They ran a ten-week course in which they used anime to teach Japanese. They engaged in activities such as active viewing, repetition, and follow-up discussion in the classroom. Participants were found to be able to recognize and understand certain linguistic features, like different levels of politeness, casual forms, dirty words, and a few other features. The researchers proposed that anime be included in the JFL classroom not just as an effective teaching tool, but also to improve learners' awareness of the language and cultural stereotypes found in anime.

\section{Research Methodology}

The study was conducted through a quantitative method, utilizing Google Forms to create a survey. Links of the survey were sent to students taking Japanese language courses levels one to three, the first semester of the 2021/2022 academic session. A total of 555 students answered this survey with $95.9 \%$ being Malays and the rest being Bumiputra from Sabah, Sarawak, and the Peninsula. $63.1 \%$ or 350 respondents were female students, and the rest were male students with $96.4 \%$ aged between $18-23$ years and the remainders were of age between $24-30$ years.

The questions are divided into two sections: the respondents' backgrounds and anime culture and in the form of multiple choices, checkboxes, and the linear scale. In the anime culture section, the questions are related to Japanese language skills, favourite types, genres of manga/anime, and the use of Japanese popular culture as a Japanese language learning tool.

The same survey was used by Roslina (2020) involving respondents in Universiti Putra Malaysia and Universiti Malaysia Terengganu, as the author would like to see the patterns of Japanese popular culture usage among university students and different usage patterns if any. Her study involved only 104 respondents while the respondents involved in the current study are a far bigger number at 570 . This unequal comparison caused the authors to use the percentage of respondents involved rather than the number of respondents.

\section{Results}

\section{The Use of Popular Culture among UiTM Students}

Figure 1 below shows that anime is the most popular culture product among UiTM students at $89 \%$ or 490 respondents, followed by song (69\%), manga (64.1\%), seiyu (34.2\%), cosplay (22.7\%), fashion ( $25.2 \%$ ) and VTuber (13.5\%). The findings of this study coincide with the findings of the study of Roslina et al (2020) in terms of the position of anime, song, manga, cosplay, fashion, and seiyu. On the other hand, just about five UiTM students, on average, watch dramas or movies. The song that the respondent meant was most likely an anime OST song. However, researchers need to identify the 'song' that is meant to be either an anime song or a J-Pop song. 
Figure 1: Popular culture preferred by UiTM students

Choose your interest in Japanese culture. * You can click more than one.

566 responses

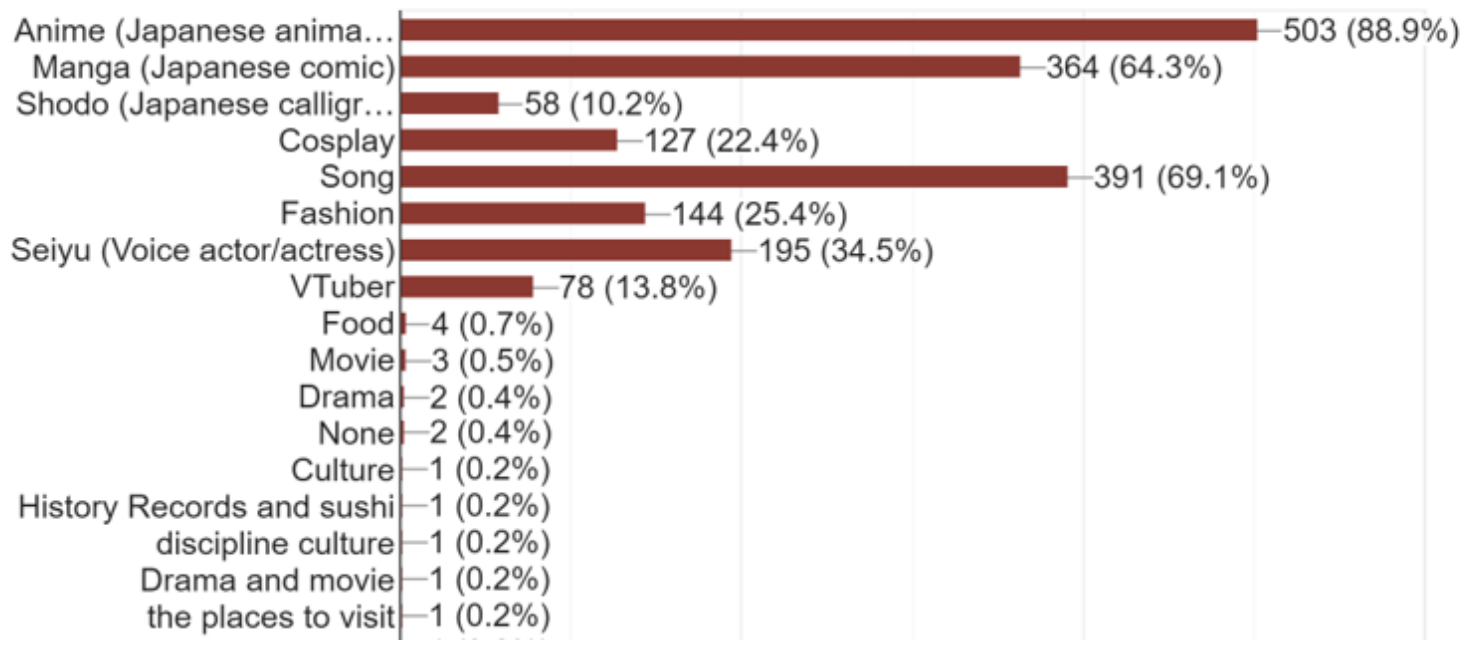

\section{Anime Genre}

Figure 2 below depicts the most popular genres among the respondents, which include fantasy (78.6\%), a love story (61.2\%), humour (60.7\%), mystery (59.5\%), horror (47.1\%), Mecha (20.2\%), and erotism or moe (12.1\%). When compared to the previous study by Roslina (2020) in figure 3, respondents' interest in a particular genre is consistent.

Figure2: Anime genre preferred by UiTM students

What genre of anime do you like? * You can click more than one.

567 responses

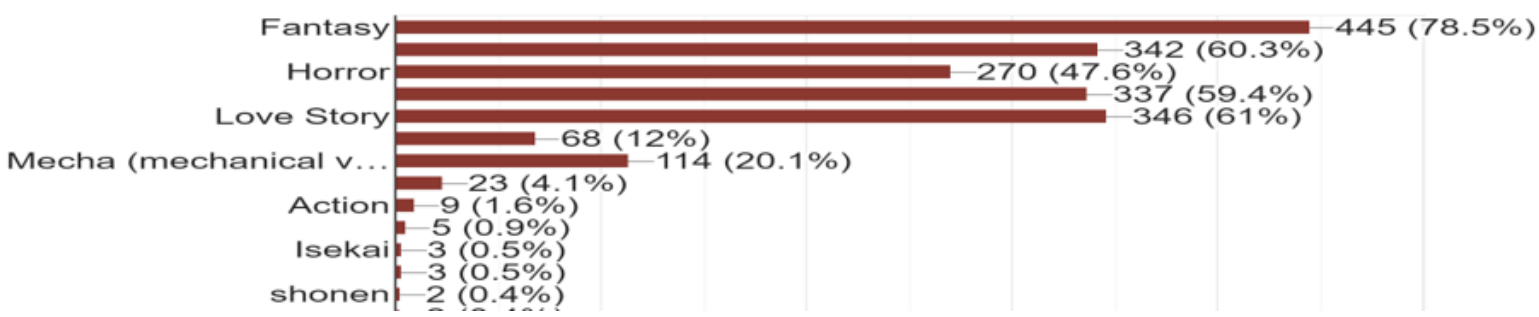

\section{Anime Type}

Figure 3 shows the type of anime that respondents prefer. Respondents preferred seinen type anime (63\%), followed by shojo (38.1\%), adult (35.1\%), both shojo and seinen (29.9\%), yaoi, and BL (11.1\%), adult and BL (9.6\%). 10.2\% liked seinen and kodomo types and $15 \%$ liked kodomo (children)'s type anime. $10.2 \%$ of students are completely uninterested in anime. 
Figure 3: The type of anime preferred by UiTM students

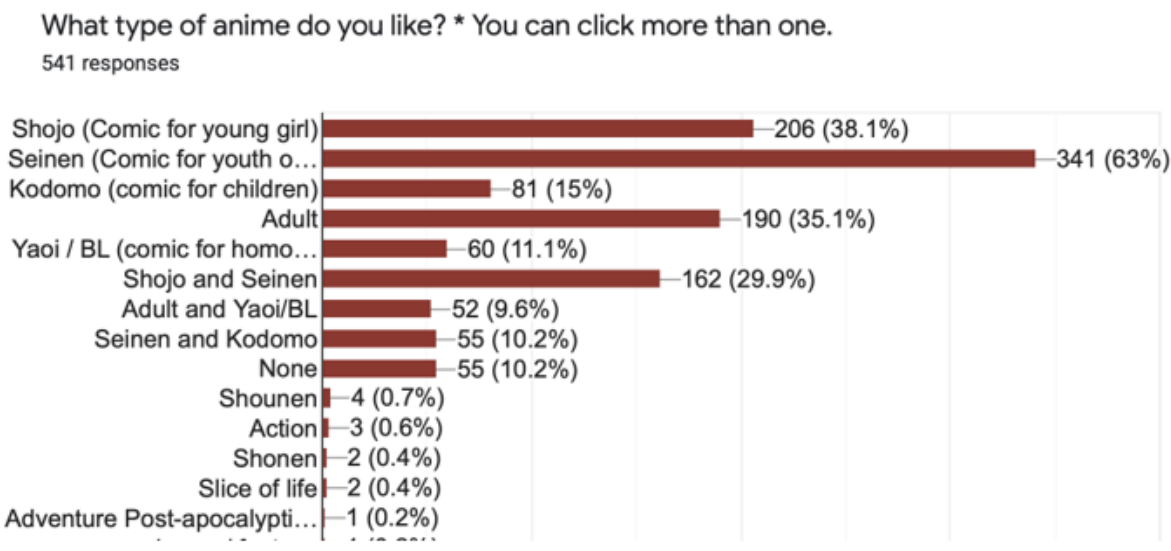

\section{Hours Spent on Japanese Popular Culture}

Figure 4 shows the number of hours the students spend on Japanese popular culture in a week. Hours spent on popular culture mean their time spent either watching videos, playing games, reading manga, or any activities related to Japanese popular culture. The result indicates that the biggest percentage of students (64.2\%) spend 1-5 hours weekly on Japanese popular culture. $15.4 \%$ spend $6-10$ hours, and $8.9 \%$ spend more than 10 hours and 0 hours respectively.

Figure 4: Hours spent on Japanese popular culture How many hours per week do you spend on Japanese popular culture? 551 responses

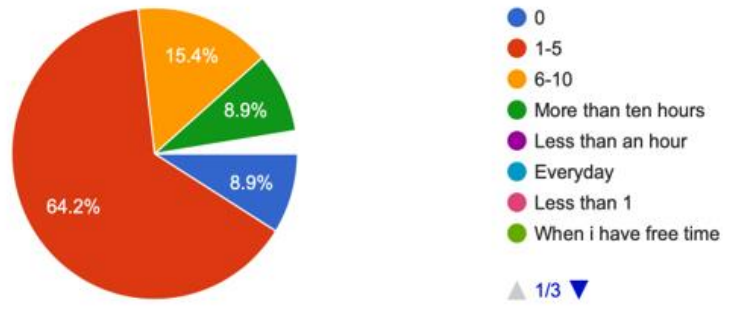

\section{Vtuber}

A VTuber is a combination of the phrase "virtual YouTuber." It's the term for a type of online content creator who uses a virtually generated avatar while streaming to their audience. The content creator creates anime characters and makes cute voices while communicating live with the audience. Figure 5 below shows that $47.4 \%$ of the respondents do not know about Vtuber, $42.3 \%$ know about Vtuber, and $10.2 \%$ answer with "maybe". This shows that less than half of the respondents do not have any idea about what Vtuber is. Vtuber is a relatively recent phenomenon in popular culture, therefore this predicament isn't surprising. 
Figure 5: Vtuber

Do you know the term "V-Tuber"?
567 responses

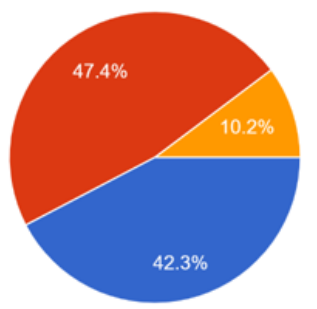

Yes

Maybe

\section{Cosplay}

Cosplay is the act of dressing up as a character or concept. People who do it regularly are called 'cosplayers'. Cosplayers can even 'role-play' as characters, mimicking their mannerisms and actions, in addition to replicating their character's clothes. Suhaeb et. al (2021) found in their study that the need to look different from others and be the center of attention of others is a cosplayer in their daily lives so that they become part of the Japanese pop culture lifestyle industry. In the current study, when asked whether they like cosplay or do they want to become a cosplayer, most of the answers are Neutral (30.3\%), Disagree $(28 \%)$, and Strongly disagree (24.2\%). Meanwhile Strongly Agree (6.9\%) and Agree (0.6\%). These figures show that most of the respondents disagree with the question that was asked whether they like cosplay and want to become a cosplayer themselves.

Figure 6: Cosplay

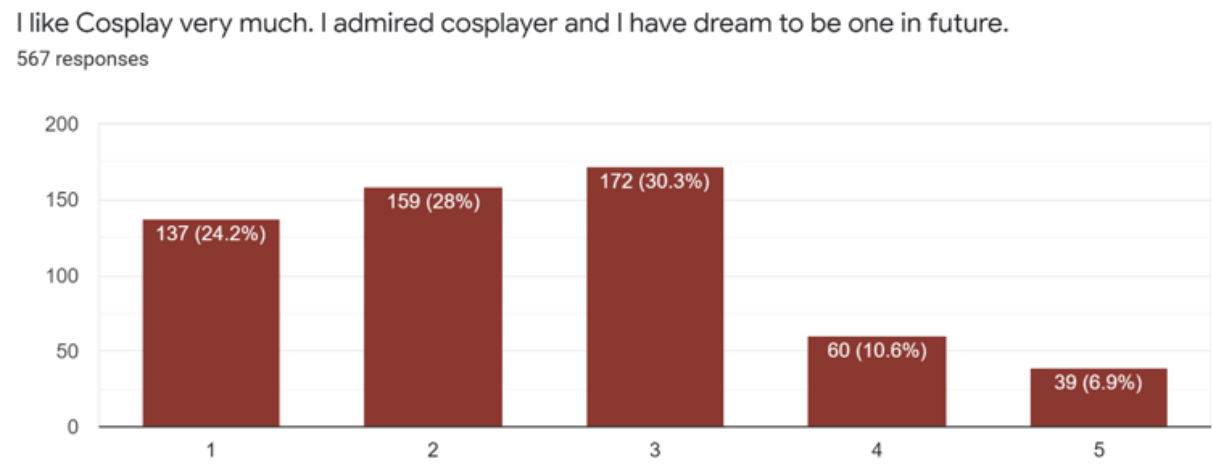

\section{Culture Product as a Tool to Improve the Japanese Language}

Many students use cultural products as a learning tool, or at least to influence many modern students to study Japanese, and they provide a significant channel through which they connect with the Japanese language and culture (Roslina, 2021). Figure 7 demonstrates that $89 \%$ of respondents consider anime to be a cultural product that aids their Japanese learning. Song is chosen by $67.4 \%$ of respondents, manga by $54.4 \%$, and seiyu by $25.4 \%$. 
Figure 7: Cultural products used to help improve the Japanese language

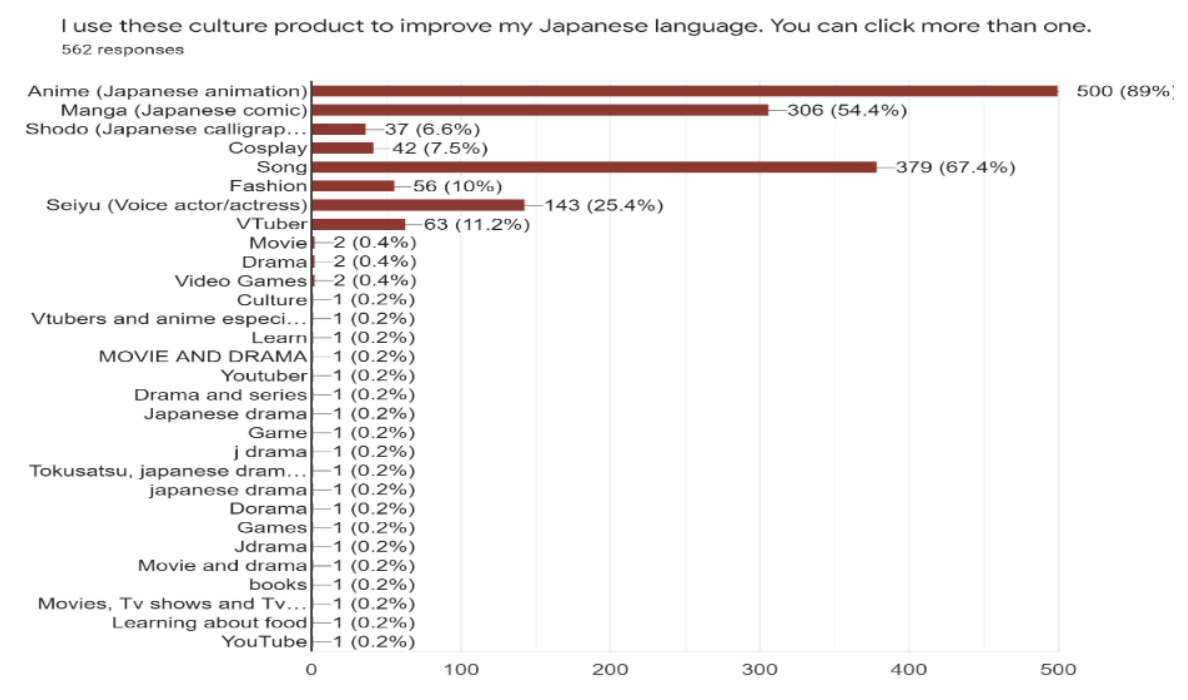

\section{Conclusion}

The results of this study show that UiTM's JFL students have a high interest in Japanese popular culture. However, their level of interest or involvement can still be considered as moderate, and not too obsessed with animation, manga, video games, and the fantasy world. The results show that although they are interested in cosplay, for example, they do not want to be a cosplayer. Their interest in cosplay is not to the extent that they want to be cosplayers themselves. Regarding the recent phenomenon Vtuber, although some already know about Vtuber, unfortunately, many still do not know what Vtuber is.

This study is important because it provided solid testimonies for the acceptance of Japanese popular culture among UiTM students. Based on their involvement and knowledge of Japanese popular culture, it can be concluded that the students have a strong interest in it. Since popular culture and the Japanese language are so closely related, students' interest in popular culture might help them develop an interest in the Japanese language as well. This study shows that most respondents watch anime, read manga and listen to songs and seiyu. Thus, it is recommended that language teachers use anime, manga, songs, and seiyu as part of the teaching support tool. Teachers should play a role to introduce and guide their students to the relevant and suitable genre and title of manga or anime to learn natural conversation. Teaching and studying Japanese in class is insufficient and monotonous, so students, particularly those who struggle with Japanese conversation, may use some popular culture as a supporting tool. For future research, it is suggested that research be conducted on the relationship between students' performance and students' interests or involvement in this popular culture.

\section{References}

Chan, Y. H., and Wong, N. L. (2017). Learning Japanese through Anime. Journal of Language Teaching and Research, Vol. 8, No. 3, pp. 485-495, May 2017. DOI: http://dx.doi.org/10.17507/jltr.0803.06

Manion, A. (2005). Discovering Japan: Anime and learning Japanese culture. Unpublished Master's thesis, University of Southern California. 
https://citeseerx.ist.psu.edu/viewdoc/download?doi=10.1.1.614.7763\&rep=rep1\&typ $\mathrm{e}=\mathrm{pdf}$

Mamat, R. (2021). The Use of Popular Cultural Products in Language Learning: A Case Study of Japanese Language Students in Malaysian Public Universities. International Journal of Academic Research in Business and Social Sciences. 429-434. http://dx.doi.org/10.6007/IJARBSS/v11-i10/11096.

Mamat, R., Abd Rahim, N., Affendi, N. R. N. M., \& Abdul Rashid, R. (2019). Perkembangan Komik dan Animasi: Satu Kajian Perbandingan antara Melayu dan Jepun [Comic and animation development: Comparative study between Malay and Japan]. Malaysian Journal of Communication. 35(2).58-274. http://journalarticle.ukm.my/13203/1/27219-104692-1-PB.pdf

Mamat, R., Abdul Rashid, R., Mansor, N. S., \& Abdul Halim, H. (2018). Penggunaan manga dan anime sebagai media pembelajaran dalam kalangan pelajar bahasa Jepun di Universiti Awam Malaysia [Manga and anime as learning tools among Malaysian public university students] Journal of Communication. 34(3). 298-313. https://doi.org/10.17576/JKMJC2018-3403-18

Seaton, P., and Yamamura, T. (2015). Japanese Popular Culture and Contents Tourism Introduction, Japan Forum, 27:1, 1-11, DOI: 10.1080/09555803.2014.962564

Suhaeb, F. W., Anggraeni, N., Ridha, M. R., Torro, S. (2021). Consumerism of Japanese Popular Culture in the Cosplayer Lifestyle. Advances in Social Science, Education and Humanities Research, volume 603. https://dx.doi.org/10.2991/assehr.k.211130.111 